\author{
Wojciech Pocheć \\ Wydział Prawa, Prawa Kanonicznego i Administracji \\ Katolicki Uniwersytet Lubelski, Lublin
}

\title{
Prokura. Istotna instytucja dla przedsiębiorcy rejestrowego
}

Przedsiębiorcą, w rozumieniu art. $43^{1}$ k.c. ${ }^{1}$, jest osoba fizyczna, osoba prawna i jednostka organizacyjna, o której mowa w art. $33^{1}$ k.c., prowadząca we własnym imieniu działalność gospodarczą lub zawodową. Ustawa prawo działalności gospodarczej² doprecyzowuje tę definicje podając, że jest to osoba fizyczna, osoba prawna oraz nie mająca osobowości prawnej spółka prawa handlowego, która zawodowo, we własnym imieniu podejmuje i wykonuje działalność gospodarczą.

Działalnością gospodarczą jest natomiast, w rozumieniu tejże ustawy, zarobkowa działalność wytwórcza handlowa, budowlana, usługowa oraz poszukiwanie, rozpoznawanie i eksploatacja zasobów naturalnych, wykonywana w sposób zorganizowany i ciągły. Przy prowadzeniu działalności gospodarczej przedsiębiorca posługuje się zorganizowanym zespołem składników niematerialnych i materialnych (wyodrębnionym właśnie na potrzeby tej działalności), czyli przedsiębiorstwem. Jednak by podjąć działalność gospodarczą część przedsiębiorców musi najpierw uzyskać wpis do odpowiedniego rejestru, obowiązek, a także podmioty, które podlegają wpisowi do rejestru reguluje art. 36 ustawy o Krajowym Rejestrze Sądowym ${ }^{3}$.

Przedsiębiorca, podlegający obowiązkowi wpisu do KRS, prowadząc działalność gospodarczą nierzadko zarządza majątkiem, który jest w znacznej części rozproszony, np. przedsiębiorstwo oprócz zakładu głównego może posiadać kilkanaście zagranicznych oddziałów położonych w różnych państwach. Powoduje to sytuację, w której każdy oddział dokonuje wielu czynności prawnych, często do ważności tych czynności niezbędne jest złożenie oświadczenia woli przez przedsiębiorcę, a nie zawsze jest to możliwe. Właśnie dla takiego, ale nie tylko, przypadku powołano instytucję, która ułatwia i usprawnia obrót gospodarczy, tą instytucją jest prokura (w tej konkretnej sytuacji jest to prokura oddziałowa). Prokura jest szczególnym rodzajem pełnomocnictwa.

Przepis art. $95 \S 1$. k.c. stanowi, iż z zastrzeżeniem wyjątków w ustawie przewidzianych albo wynikających z właściwości czynności prawnej, można dokonać czynności prawnej przez przedstawiciela, natomiast $\S 2$ stanowi, że czynność prawna dokonana przez przedstawiciela $\mathrm{w}$ granicach umocowania pociąga za sobą skutki bezpośrednio dla reprezentowanego.

Naturą prawną przedstawicielstwa jest wedle założeń teorii reprezentacyjnej (Repräsentionstheorie), że w razie dokonania czynności prawnej przez przedstawiciela, ten ostatni składa własne oświadczenie woli, tyle że czyni to w imieniu i z bezpośrednimi skutkami dla

\footnotetext{
${ }^{1}$ Ustawa z dnia 23 kwietnia 1964 Kodeks cywilny (Dz. U. nr 16, poz. 93).

${ }^{2}$ Ustawa z dnia 19 listopada 1999 Prawo działalności gospodarczej (Dz. U. nr 101, poz. 1178).

${ }^{3}$ Ustawa z dnia 20 sierpnia 1997 Krajowy Rejestr Sądowy (Dz. U. nr 17, poz. 209).
} 
reprezentowanego (R. Ihering, J. Hupka). Przesłankę przypisania reprezentowanemu skutków zachowania się przedstawiciela stanowi więc istnienie umocowania (art. 95 § 2 k.c.) $)^{4}$. Umocowanie może się opierać na ustawie ${ }^{5}$ (przedstawicielstwo ustawowe) albo na oświadczeniu reprezentowanego (pełnomocnictwo) - art. 96 k.c.

Jako odmiana przedstawicielstwa ustawowego traktowane jest przysługujące, z mocy art. 866 k.c., każdemu wspólnikowi spółki cywilnej umocowanie do reprezentowania spółki.

Przedstawicielstwo zwykło się dzielić na czynne i bierne. Kryterium podziału stanowi charakter zachowania się, do którego umocowany jest przedstawiciel. Umocowanie przedstawiciela czynnego obejmuje bowiem dokonanie czynności prawnej, a więc w szczególności złożenie oświadczenia woli, natomiast umocowanie przedstawiciela biernego zawiera się jedynie w odbiorze oświadczenia woli.

Umocowanie przedstawicieli ustawowych wynika $\mathrm{z}$ odpowiednich ustaw i charakteryzuje się silną pozycją prawną wobec osoby reprezentowanej co wydaje się zrozumiałe, ze względu na wiek lub stan zdrowotny reprezentowanego.

Zgoła odmiennie natomiast przedstawia się ta sytuacja w przypadku pełnomocnictwa. Pełnomocnictwo wynika $\mathrm{z}$ oświadczenia woli reprezentowanego (mocodawcy). Nie można udzielić pełnomocnictwa do dokonywania wszelkich czynności prawnych, pełnomocnictwo takie stwarzałoby zbyt duże niebezpieczeństwo dla mocodawcy. Dlatego też na powstanie pełnomocnictwa, jego wygaśnięcie, jak i zakres ogromny wpływ wywiera oświadczenie woli mocodawcy.

Ze względu na zakres umocowania wyróżnia się trzy rodzaje pełnomocnictwa:

1) pełnomocnictwo ogólne,

2) pełnomocnictwo do czynności prawnych określonego rodzaju (pełnomocnictwo rodzajowe),

3) pełnomocnictwo do poszczególnej czynności prawnej (pełnomocnictwo szczególne).

Ad. 1) Pełnomocnictwo ogólne obejmuje zgodnie z art. 98 k.c. umocowanie do czynności zwykłego zarządu.

Ad. 2) Pełnomocnictwo do czynności prawnych określonego rodzaju (nazywane pełnomocnictwem rodzajowym) obejmuje umocowanie do dokonywania czynności prawnych mieszczących się w określonej grupie czynności prawnych.

Ad. 3) Pełnomocnictwo do poszczególnej czynności prawnej (nazywane pełnomocnictwem szczególnym), obejmuje umocowanie do ściśle określonej czynności.

Ad. 3a) Prokura - odmiana pełnomocnictwa szczególnego, wyróżniająca się tym, iż zakres umocowania prokurent wynika wprost $\mathrm{z}$ ustawy, po drugie zaś to, że jest bardzo szeroki (upodobniając się pod tym względem do przedstawicielstwa ustawowego) i to właśnie ta instytucja jest niezwykle ważna dla przedsiębiorcy rejestrowego.

Należy nadmienić, że prokura jako urządzenie związane z prawem handlowym powstała dość szybko po odzyskaniu niepodległości w 1918 r. Dekret o rejestrze handlowym z 1919 r. nie tylko przewidywał regulacje prokury, ale przede wszystkim precyzował zakres podmiotowy tej regulacji. Od początku regulacji prokury w prawie polskim ustawodawca zdecydowany był powiązać zakres podmiotowy prokury z zakresem podmiotowym rejestru handlowego. Takie ogólne założenia zrealizowano konsekwentnie także w kodeksie handlowym z 1934 r. Prokura była w myśl art. 61 k.h. formalnym nieograniczonym pełnomocnictwem handlowym do prowadzenia cudzego przedsiębiorstwa zarobkowego $\mathrm{w}$ imieniu i na rachunek tej osoby, bądź fizycznej, bądź prawnej, która prokurę ustanowiła oraz podpisywa-

\footnotetext{
${ }^{4}$ E. Drozd, B. Kordasiewicz, M. Pazdan, Z. Radwański, A. Zieliński. System Prawa Prywatnego. Tom 2. Prawo cywilne. Część ogólna. Warszawa 2002 s. 456-457.

${ }^{5}$ Ustawa z dnia 25 lutego 1964 Kodeks rodzinny i opiekuńczy (Dz. U. nr 9, poz. 59). Przedstawicielami ustawowymi małoletniego są rodzice, sprawujący władzę rodzicielską (art. 98 k.r.o.) lub opiekun (art. $155 \S 2$ i n. k.r.o.), ubezwłasnowolnionego całkowicie - opiekun (art. 14 § 2 k.c.), ubezwłasnowolnionego częściowo - kurator (art. $16 \S 2$ k.c. ).
} 
nia firmy do której prokura się odnosi. Prokura zarówno pod rządami dekretu o rejestrze handlowym, jak i k.h. realizowała charakterystyczne funkcje norm prawa handlowego: zapewnienie koniecznej dynamiki stosunkom handlowym przy optymalnym zabezpieczeniu uzasadnionych interesów osób trzecich, wchodzących w stosunki prawne i faktyczne z kupcem rejestrowym. Uregulowanie prokury w k.h. jako szczególnego rodzaju pełnomocnictwa było dostosowane do potrzeb obrotu gospodarczego. Obowiązek ujawnienia prokury w rejestrze handlowym pozwalał osobom trzecim bez trudu zorientować się komu prokury udzielono, a prokurentowi ułatwiał wykazanie, że jest on legitymowanym do działania w imieniu i na rzecz oznaczonego kupca.

Kolejną ważną regulacją dotyczącą prokury był art. VI $\S 1$ przepisów wprowadzających k.c., który uchylił przepisy k.h. oraz przepisy wprowadzające k.h. z wyjątkiem przepisów obu rozporządzeń dotyczących spółek, spółek z ograniczoną odpowiedzialnością i spółek akcyjnych, przy czym w stosunku do tych spółek pozostały również w mocy przepisy rozporządzeń o firmie, prokurze i rejestrze handlowym.

Z dniem 1 stycznia 2001 r. kodeks spółek handlowych uchylił utrzymane w mocy przez art. VI p. w. k.c. przepisy k.h., z wyjątkiem przepisów dotyczących firmy i prokury.

Prace nad „Projektem zmian kodeksu cywilnego w zakresie przedstawicielstwa (prokury) wraz z uzasadnieniem" (zwany dalej Projektem) podjęła Komisja Kodyfikacyjna Prawa Cywilnego działająca pod przewodnictwem Z. Radwańskiego już w drugiej połowie 1999 r., a ostatecznym dziełem tej komisji był Projekt opracowany w styczniu 2000 r.

Propozycja ta zakładała przeniesienie regulacji prawnej instytucji prokury do kodeksu cywilnego, co należało uznać za zabieg legislacyjny zasługujący na pełną aprobatę, a to ze względu na jego zgodność z przyjętą koncepcją jedności prawa cywilnego. Należy jednak podkreślić, że projekt zmiany regulacji prawnej prokury był spóźniony przez fakt jego czasowego niezsynchronizowania $\mathrm{z}$ wejściem w życie kodeksu spółek handlowych

Projekt Komisji Kodyfikacyjnej Prawa Cywilnego został zaakceptowany i dnia 14 lutego uchwalono ustawę, która stanowi nowe przepisy o prokurze oraz przenosi instytucje prokury z k.h. do k.c. Przepisy te znalazły się w dziale VI - przedstawicielstwo, art. od $109^{1}-109^{9}$ k.c. $Z$ dniem 25 września 2003 r. weszły w życie nowe przepisy o prokurze.

Prokura jest pełnomocnictwem udzielonym przez przedsiębiorcę podlegającemu obowiązkowi wpisu do rejestru przedsiębiorców, które obejmuje umocowanie do czynności sądowych i pozasądowych, jakie są związane z prowadzeniem przedsiębiorstwa (art. $109^{1}$ $\S 1$ k.c.).

Zakres prokury według art. $109^{1} \S 1$ k.c. jest określony w sposób bezwzględnie obowiązujący, nie może więc, ani wykraczać poza umocowanie do dokonania sądowych i pozasądowych czynności prawnych związanych z prowadzeniem przedsiębiorstwa, ani nie może być ograniczony. Udzielić prokury może jak wynika expressis verbis przedsiębiorca podlegający obowiązkowi wpisu do $\mathrm{KRS}^{6}$.

Wyłączona jest możliwość ograniczenia umocowania prokurent ze skutkiem wobec osób trzecich, z wyjątkiem przepisów przewidzianych w ustawie (art. $109^{1} \S 2$ k.c.).

Art. $109^{2} \S 1$ k.c. zastrzega dla prokury zachowanie formy szczególnej (ad solemnitatem). Formę tę określa art. $73 \S 1$ k.c. i jest nią forma pisemna lub oświadczenie woli złożone w drodze elektronicznej, opatrzone bezpiecznym podpisem elektronicznym weryfikowanym przy pomocy ważnego kwalifikowanego certyfikatu, ponieważ według art. $78 \S 2$ k.c. takie oświadczenie woli jest równoznaczne $\mathrm{z}$ oświadczeniem woli złożonym $\mathrm{w}$ formie pisemnej. Nie zachowanie jednej z tych form skutkuje nieważnością czynności prawnej ${ }^{7}$.

\footnotetext{
${ }^{6}$ L. Moskwa. Prokura w świetle projektowanych zmian. Prawo Spółek 2001 nr 9, s. 20.

${ }^{7}$ S. Dmowski, S. Rudnicki. Komentarz do kodeksu cywilnego. Księga pierwsza. Cześć ogólna. Warszawa 2003 s. 399.
} 
Art. $109^{2} \S 2$ k.c. stanowi natomiast, że prokurentem można ustanowić tylko osobę fizyczną mającą pełną zdolność do czynności prawnych ${ }^{8}$.

Bardzo szeroki zakres umocowania prokurenta wymaga od ustawodawcy zakreślenia wyraźnych granic tego umocowania, ze względu na ryzyko, jakie z takim zakresem jest związane. Przepis art. $109^{3}$ k.c. wyłącza w ramach prokury udzielenie osobie będącej prokurentem pełnomocnictwa do czynności określonego rodzaju, obejmujących czynności w tym przepisie wymienione. Do dokonania tych czynności przekraczających zakres prokury prokurent musi mieć osobne pełnomocnictwo do poszczególnej postaci (art. 98 k.c.) ${ }^{9}$.

Prokura może być udzielona kilku osobą łącznie lub oddzielnie, takie zdanie zawiera art. $109^{4} \S 1$ k.c. Przepis ten stwarza przedsiębiorcy szerokie możliwości bowiem w razie ustanowienia prokury łącznej podmiotem prokury staje się zespół osób, natomiast dla ważności czynności prawnej konieczne jest współdziałanie dwóch lub więcej prokurentów łącznych. Wykluczone jest zatem ustanowienie prokury łącznej jednej osobie ${ }^{10}$. W razie braku zastrzeżenia łączności prokury, uważa się, że została ona udzielona oddzielnie. Prokura udzielona kilku osobą oddzielnie legitymuje każdego osobno do działania w granicach ustawowego umocowania.

Art. $109^{4} \S 2$ k.c. został natomiast wprowadzony ze względu na ochronę zaufania osób trzecich. Oświadczenie woli skierowane do któregokolwiek z prokurentów łącznych jest każdorazowo skuteczne względem przedsiębiorcy, to samo odnosi się do doręczenia pisma.

Przepis art. $109^{5}$ k.c. wprowadza pojęcie prokury oddziałowej, czyli prokury ograniczonej do zakresu spraw wpisanych do rejestru oddziału przedsiębiorstwa. Wprowadzono ten rodzaj prokury ponieważ przemawiał za tym interes przedsiębiorcy. Daje ona przedsiębiorcy możliwość ustanowienia prokury osobie zorientowanej wyłącznie w sprawach konkretnego oddziału (działającego na wyodrębnionym terenie, posiadającego własną klientele i własne specyficzne jedynie dla niego interesy).

Art. $109^{6}$ k.c. stanowi o tym, że prokura nie może być przeniesiona. Prokurent może jednak ustanowić pełnomocnika do poszczególnej czynności lub czynności pewnego rodzaju. Wyłącza ten przepis uprawnienie prokurenta do udzielenia prokury substytucyjnej i pełnomocnictwa ogólnego, chroniąc w ten sposób przedsiębiorcę przed nadużyciem udzielonej przez niego prokury.

Prokura może być odwołana w każdym momencie. W spółkach osobowych może odwołać prokurę każdy wspólnik mający prawo prowadzenia spraw spółki, natomiast w spółkach kapitałowych każdy członek zarządu ${ }^{11}$. Prokura wygasa zawsze z chwilą wykreślenia przedsiębiorcy $\mathrm{z}$ rejestru przedsiębiorców, a także ogłoszenia upadłości, otwarcia likwidacji oraz przekształcenia przedsiębiorstwa. Prokura wygasa również wraz ze śmiercią prokurenta. Śmierć przedsiębiorcy ani utrata przez niego zdolności do czynności prawnych nie powoduje wygaśnięcia prokury (art. $109^{7} \S 1-4$ k.c.).

Udzielenie i wygaśnięcie prokury przedsiębiorca powinien zgłosić do rejestru przedsiębiorców. Zgłoszenie o udzieleniu prokury powinno określać jej rodzaj, a w przypadku prokury łącznej także sposób jej wykonywania. Rejestrem właściwym dla tego typu wpisów jest KRS (art. $109^{8} \S 1-2$ k.c.).

Przepis art. $109^{9}$ k.c. określa, w jaki sposób powinien podpisywać się prokurent. Prokurent składa własnoręczny podpis zgodnie ze znajdującym się w aktach rejestrowych wzo-

\footnotetext{
${ }^{8}$ P. Bielski. Prokura jako instytucja prawa przedsiębiorców rejestrowych. Przegląd Prawa Handlowego 2001 nr 9 s. 47.

${ }^{9}$ M. Pazdan. O rolach, w jakich może występować prokurent przy dokonywaniu czynności prawnych. Rejent 2003 nr 12, s. 14-15.

${ }^{10}$ A. Buchenfeld. Prokura łączna nieprawidłowa. Wybrane zagadnienia. Palestra 2003 nr 5/6, s. 31-33.

${ }^{11}$ A. Wilkowska-Płóciennik, Firma i prokura w kodeksie cywilnym. Prokuratura i Prawo 2004 nr 3, s. $155-156$.
} 
rem podpisu, wraz z dopiskiem wskazującym na prokurę, chyba że z treści dokumentu wynika, że działa jako prokurent. Prokurent może jednak składać równoważne, do oświadczenia woli złożonego w formie pisemnej, oświadczenie woli opatrzone bezpiecznym podpisem elektronicznym weryfikowanym przy pomocy ważnego kwalifikowanego certyfikatu (art. 78 $\S 2$ k.c. $)^{12}$.

Podsumowując, prokura jest niezwykle ważnym instrumentem w prowadzeniu przedsiębiorstwa przez przedsiębiorcę rejestrowego. To pełnomocnictwo ma bardzo szeroki zakres i wychodzi na przeciw potrzebom (zarówno prawnym, jak i gospodarczym) uczestników obrotu gospodarczego. Zaletą tak ukształtowanego przedstawicielstwa jest przede wszystkim ustawowe określenie zakresu umocowania prokurenta, co bezpośrednio skutkuje na zwiększenie bezpieczeństwa prawnego. W dzisiejszych warunkach gospodarczych prokura jest wręcz nieodzowna przy prowadzeniu przedsiębiorstwa i dobrze, że instytucja ta została uregulowana przez ustawodawcę, gdyż w wyraźny sposób przyczynia się do zapewnienia bezpieczeństwa, ułatwienia i usprawnienia obrotu gospodarczego.

\section{LITERATURA}

Bielski P., Prokura jako instytucja prawa przedsiębiorców rejestrowych. Przegląd Prawa Handlowe-go $2001 \mathrm{nr} 9$. .

Buchenfeld A. Prokura łaczna nieprawidlowa. Wybrane zagadnienia. Palestra 2003 nr 5/6.

Dmowski S., Rudnicki S., Komentarz do kodeksu cywilnego. Księga pierwsza. Cześć ogólna. Warszawa 2003.

Drozd E., Kordasiewicz B., Pazdan M., Radwański Z., Zieliński A., System Prawa Prywatnego. Tom 2. Prawo cywilne. Część ogólna. Warszawa 2002.

Moskwa L., Prokura w świetle projektowanych zmian. Prawo Spółek $2001 \mathrm{nr} 9$.

Pazdan M., O rolach, w jakich może wystepować prokurent przy dokonywaniu czynności prawnych. Rejent $2003 \mathrm{nr} 12$.

Siemiątkowski T., Instytucja prokury w projekcie Komisji Kodyfikacyjnej Prawa Cywilnego. Przegląd Sądowy $2002 \mathrm{nr} 5$.

Ustawa z dnia 19 listopada 1999 Prawo działalności gospodarczej (Dz. U. nr 101, poz. $1178)$.

Ustawa z dnia 20 sierpnia 1997 Krajowy Rejestr Sądowy (Dz. U. nr 17, poz. 209).

Ustawa z dnia 23 kwietnia 1964 Kodeks cywilny (Dz. U. nr 16, poz. 93).

Ustawa z dnia 25 lutego 1964 Kodeks rodzinny i opiekuńczy (Dz. U. nr 9, poz. 59).

Wilkowska-Płóciennik A., Firma i prokura w kodeksie cywilnym. Prokuratura i Prawo 2004 nr 3.

\footnotetext{
${ }^{12}$ T. Siemiątkowski. Instytucja prokury w projekcie Komisji Kodyfikacyjnej Prawa Cywilnego. Przegląd Sądowy 2002 nr 5, s. 114-115.
} 